\title{
MORPHOLOGICAL ERROR ANALYSIS ON STUDENT'S ENGLISH NARRATIVE COMPOSITION: A SURVEY AT PRIVATE UNIVERSITY IN EAST JAKARTA
}

\author{
Andi Santoso \\ Program of English Education, Faculty of Language and Art, University of Indraprasta PGRI \\ Jalan Nangka No. 58C Tanjung Barat, Jagakarsa, Jakarta Selatan 12530 \\ andynabil@gmail.com
}

\begin{abstract}
The objectives of the research are to know the errors made by the learners in their English narrative composition; to identify the factors the learners made the errors; to identify the errors made by the learners; to correct the errors which have been made; to improve the teaching quality which is appropriate with the curriculum and the syllabus; as well as to get the data and the explanation about the difficulties in studying English especially in arranging the English narrative composition. The method used in this research is descriptive method that gives the data and the explanation about the recent symptoms of the errors made by the learners. The descriptive method consists of the ways in giving the note, the analysis and the interpretation about the recent condition. The characteristic of the descriptive method is to give the existence of the data which is straight to the problems as the recent variables are not manipulated. The research was carried out by conducting a written test about English narrative composition to the learners. After analyzing the data, the findings point out that the errors of derivational morphology is $10.3 \%$ and the inflectional morphology releases in $89.7 \%$.
\end{abstract}

Key words: morphology, narrative composition, error analysis

\begin{abstract}
ABSTRAK
Tujuan penelitian ini adalah untuk mengetahui jenis kesalahan yang dilakukan oleh para pelajar dalam membuat karangan narasi dalam bentuk bahasa Inggris; untuk mengidentifikasi berbagai faktor kesalahan dalam melakukan kesalahan penulisan; untuk membenarkan kesalahankesalahan penulisan yang dilakukan oleh para pelajar; untuk meningkatkan kualitas pengajaran yang sesuai dengan kurikulum dan silabus serta untuk mendapatkan data dan penjelasan mengenai kesulitan dalam belajar bahasa Inggris khususnya dalam menyusun karangan narasi dalam bentuk bahasa Inggris. Metode yang digunakan dalam penelitian ini adalah metode deskriptif yaitu suatu metode yang mencoba memberikan data dan menjelaskan dengan cara memberikan catatan, menganalisa, menafsirkan keadaan saat ini. Ciri khas metode discriptif adalah suatu metode dengan menggunakan data yang ada, fokus pada masalah dan variabel tidak dimanipulasi oleh peneliti. Penelitian ini dilakukan dengan tes penulisan karangan narasi dalam bahasa Inggris. Setelah menganalisis data, hasil penelitian menunjukkan bahwa kesalahan dalam bentuk derivational morphology adalah sebesar $10.3 \%$ sedangkan kesalahan dalam inflectional morphology adalah sebesar $89.7 \%$.
\end{abstract}

Kata kunci: morfologi, karangan narasi, analisis kesalahan 


\section{INTRODUCTION}

Just as birds have wings, men have language. The wings give the bird its peculiar aptitude for aerial locomotion. Language enables man's intelligence and passions to acquire their peculiar characters of intellect and sentiment (Blair and Rodman, 1990). A language is a set of signals by which we communicate. Human beings are not the only species to have an elaborate communication system. Bees communicate about honey and about sitting of a new hive, chimpanzees can use vocalizations to warn danger, to signal the finding of food or to indicate attitudes to mating. Dolphins can communicate information on food and danger by means of whistles and clicks.

Dealing with language, Blair and Rodman (1990) affirm that language is not an abstract construction of the learner, of or dictionary makers, but is something arising out of the work, needs, ties, joys, affections, tastes, of long generations of humanity, and has its bases broad and low, close to the ground. Furthermore, Blair and Rodman (1990:3) state that "When we study human language, we are approaching what some might call the human essence, the distinctive qualities of mind that are, so far as we know, unique to man."

Todd (2000:41) said that "Morphology is the study of morphemes which are the smallest significant units of grammar." Morphology is the study of how words are structured and how they are put together from smaller parts called as morpheme. Morpheme is the smallest meaningful part of word. Morpheme comprises of two kinds, that is, free and bound morphemes. According to William, et. al. (2005:16), "Morpheme is the smallest unit of language that carries information about meaning of function." Free morphemes can stand by themselves, while bound morphemes never occur in isolation. Free morphemes are usually bases, whereas bound morphemes are usually affixes. Morphemes which can stand by themselves as single word e.g. sit, walk, door, etc. are called free morphemes. In contrast, bound morpheme is morpheme that cannot stand alone, but typically attached to another form, e.g. -ist, -ed, $\mathrm{s}$, etc.

Akmaijan, et. al. (1995) point out that "Both derivational and inflectional morphemes are bound forms and are called affixes". It shows that there are two kinds of affixes; inflectional and derivational. Both inflectional and derivational are important factors of making grammatical sentences. In addition, derivational affixes are ones of efficient way in enlarging ones' vocabulary. Yet, students often face difficulties in using them appropriately. The difficulties in applying those affixes show the students' grammatical competence in producing the language. Thus, the students' difficulty in learning inflectional and derivational affixes needs more attention. One way to know the students' difficulty is by analyzing their errors. As Corder (1975) said what has come to be known as 'error analysis' has to do with the investigation of the language of second-language learner.

Morphology is a field of linguistics that examines internal structure of words and processes of word formation is known as morphology (Aronoff, 2009). The students' difficulties in learning about inflectional and derivational affixes on morphological item have been examined by several studies. The fact that phonological errors can occur either in isolation or in association with morphological errors could be attributed to the functional heterogeneity of phonological errors, and to the separability of the neural substrates involved in processing various aspects of 
phonological information.

The study conducted by Timothy "Morphological Errors in the English Usage of Some Nigerian". The study revealed that (a) the pupils' competence in English morphology is very low and (b) the errors were caused by such factors as the inconsistency in the morphological rules of English, overgeneralization of rules, misapplication of rules as well as the interference of the subjects' mother tongue on English.

There are two kinds of morphology, they are: derivational morphology and inflectional morphology. Derivational morphology discusses about the morphemes that can be used to form new words. It also studies the principles governing the construction of new words, without reference to the specific grammatical role a word might play in a sentence. Inflectional morphology occurs with nouns, pronouns and verbs. It also studies the way in which words vary (or "inflect") in order to express grammatical contrasts in sentences such as singular/plural or present/past tense.

Morphology based on Todd (2000) is a part of phonology and phonology has been described as the study of speech sounds and their patterns. It is a study based on the 'phoneme' or smallest significant unit of speech. Todd (2000:41) stated that "Morphology is the study of morphemes, which are the smallest significant units of grammar". This definition becomes more comprehensible on the examples: cat - cats; book - books; look looked; and watch - watched.

In linguistics, morphology is the identification, analysis and description of the structure of morphemes and other units of meaning in a language like words, affixes, and parts of speech and intonation/stress, implied context (words in a lexicon are the subject matter of lexicology). Morphological typology represents a way of classifying languages according to the ways by which morphemes are used in a language - from the analytic that uses only isolated morphemes, through the agglutinative ("stuck-together") and fusion languages that use bound morphemes (affixes), up to the polysynthetic, which compress lots of separate morphemes into single words.

When Samuel Goldwyn, the pioneer movie maker, announced that in two words: im-possible he was reflecting the common view that words are the basic meaningful units in a language. We have already seen that this view cannot be right, because some words are formed by combining a number of distinct units of meaning.

The traditional term for the most elemental unit of grammatical form is called by morpheme. The word is derived from the Greek word 'morphe', meaning form. Linguistically speaking, for example: 'impossible' is two morphemes. A single word may be composed of one or more morphemes, as shown in the following examples: one morpheme (boy, desire); two morphemes (boy + ish, desir(e) + able); three morphemes (boy + ish + ness, desir(e) + abil + ity); four morphemes (gentle + man $+\mathrm{li}+$ ness, un $+\operatorname{desir}(\mathrm{e})+$ abil + ity); and more than four morphemes (un + gentle + man $+\mathrm{li}+$ ness, anti + dis + establish + ment + ari + an + ism).

A morpheme may be defined as the minimal linguistic sign, a grammatical unit that is an arbitrary union of a sound and a meaning and that cannot be further analyzed. As we shall see, this definition may be too simple, but it will serve our proposition for now. Every word in every language is composed of one or more morphemes.

Some English morphemes, by 
category:

\begin{tabular}{ll}
\hline \multicolumn{1}{c}{ Derivational } & \multicolumn{1}{c}{ Inflectional } \\
\hline -ation & -s Plural \\
\hline -al & -s Possessive \\
\hline -ize & -ed Past \\
\hline -ic & -ing Progressive \\
\hline -y & -er Comparative \\
\hline -ous & -est Superlative \\
\hline
\end{tabular}

The possessive of all nouns:

John John's book/books

The women the women bag/bags

Irregular nouns often form their plurals by a vowel change:

Child - children

Tooth - teeth

But they form the possessive in exactly the same way as regular nouns

The dog tail the dog's tail

The student book the student's book

There is no difference in sound between a regular noun's plural form and its possessive.

The student's

The student's books

The students

The students' books

Inflectional suffixes are used to indicate present tense agreement:

I/You/They/We sing/drink

$\mathrm{He} / \mathrm{She} / \mathrm{It} \quad$ sing+s/drink+s

The present participle:

Sing+ing/drink+ing

The past tense and past participle:

I look+ed/I have look-fed

She water+ed/She has water+ed

In irregular verbs, the past tense and the past participle are often signaled by a vowel change or a vowel change plus a suffix:

$\begin{array}{lll}\text { drink } & \text { drank } & \text { drunk } \\ \text { eat } & \text { ate } & \text { eaten }\end{array}$

\section{METHOD}

The method used in this research is qualitative method. In making the research, the writer describes the type of morphological error based on the morphology criteria. The procedures of the research contain several steps, namely: identifying the errors made by the learners in their English narrative composition; identifying the factors the learners made the errors; identifying the errors made by the learners; correcting the errors which have been made; improving the teaching quality which is appropriate with the curriculum and the syllabus; as well as getting the data and the explanation about the difficulties in studying English especially in arranging the English narrative composition.

The method used in this research is descriptive method that gives the data and the explanation about the recent symptoms of the errors made by the learners. The descriptive method consists of the ways in giving the note, the analysis and the interpretation about the recent condition. The characteristic of the descriptive method is to give the existence of the data which is straight to the problems as the recent variables are not manipulated. The research was carried out by conducting a written test about English narrative composition to the learners

\section{RESULTS AND DISCUSSION}

The discussion about errors found in the learner's English narrative composition. The samples were taken from 37 learners' English narrative composition. 
Inflectional Morphology

\begin{tabular}{llll}
\hline No. Student's Sentence & Types of Error & Reconstruction
\end{tabular}

\begin{tabular}{clrrr}
\hline 1. I got some experience, Inflectional & in I got some experiences, \\
knowledge, and friends. & plural form & knowledge, and friends. \\
\hline 2. $\begin{array}{l}\text { Many people, } \\
\text { building at Jakarta. }\end{array}$ & vehicles, Inflectional & in There are many people, \\
& plural form & $\begin{array}{r}\text { vehicles, and buildings in } \\
\text { Jakarta. }\end{array}$
\end{tabular}

3. There are many tourist over Inflectional in There are many tourists
there. $\quad$ plural form over there.
4. Jakarta have many peoples and Inflectional in Jakarta has many people and vehicle. plural form vehicles.
5. Many building in Jakarta. Inflectional in There are many buildings in plural form Jakarta.
6. At building many has some Inflectional company. plural form
in In a building, it has many companies.
7. Jakarta has many problem. Inflectional in Jakarta has many problems. plural form
8. Many people Jakarta comes Inflectional from another town. plural form
in Many people of Jakarta come from other towns.

9. Most of people come here to buy Inflectional clothes, dress, bag, and plural form traditional food of Bali.

in Most of the people come here to buy clothes, dresses, bags, and traditional food of Bali

10. They don't have job in Jakarta. Inflectional plural form

in They don't have jobs in Jakarta.
11. Distance from Jakarta to Inflectional in The distance from Jakarta to Yogyakarta by road plural form thirteen hour. Yogyakarta by car is thirteen hours.

12. Many tourist who flock there. Inflectional in Many tourists flock there. plural form

13. Kind of attractions like Dufan, Inflectional in There are many kinds of seaworld, atlantis. plural form

14. It's strategis place where many Inflectional public vehicle. plural form attraction such as Dufan, Seaworld, and Atlantis.

in It's a strategic place where many public vehicles there.
15. Much a culture in Jogja town. Inflectional in There are many cultures in plural form Jogja.




\begin{tabular}{|c|c|c|}
\hline 16. There is so many culture. & $\begin{array}{l}\text { Inflectional } \\
\text { plural form }\end{array}$ & in There are so many cultures. \\
\hline $\begin{array}{l}\text { 17. Jogjakarta city is either city } \\
\text { visited the tourist. }\end{array}$ & $\begin{array}{l}\text { Infle } \\
\text { plura }\end{array}$ & $\begin{array}{l}\text { in Jogjakarta is another city } \\
\text { visited by the tourists. }\end{array}$ \\
\hline $\begin{array}{l}\text { 18. I know why the tourist very } \\
\text { often visit the Jogja. }\end{array}$ & $\begin{array}{l}\text { Infle } \\
\text { plur }\end{array}$ & $\begin{array}{l}\text { in I know why do the tourists } \\
\text { often visit Jogja? }\end{array}$ \\
\hline $\begin{array}{l}\text { 19. There is so many place the } \\
\text { vacation. }\end{array}$ & $\begin{array}{l}\text { Inflectional } \\
\text { plural form }\end{array}$ & so many places for \\
\hline 20. Good & $\begin{array}{l}\text { Infle } \\
\text { plur: }\end{array}$ & in $\mathrm{Go}$ \\
\hline $\begin{array}{l}\text { 21. Lot of restaurant, children's } \\
\text { toys, electronics, clothes. }\end{array}$ & $\begin{array}{l}\text { Infl } \\
\text { plui }\end{array}$ & $\begin{array}{l}\text { in There are a lot of } \\
\text { restaurants, } \\
\text { toys, electronics, and } \\
\text { clothes. }\end{array}$ \\
\hline $\begin{array}{l}\text { 22. Many people from outside } \\
\text { Jakarta many moved to } \\
\text { Jakarta just a look for a job. }\end{array}$ & $\begin{array}{l}\text { Inf } \\
\text { plu }\end{array}$ & $\begin{array}{l}\text { in Many people who come } \\
\text { from outside Jakarta just look } \\
\text { for jobs. }\end{array}$ \\
\hline $\begin{array}{l}\text { a has population of well } \\
\text { million. }\end{array}$ & $\begin{array}{l}\text { Infle } \\
\text { plura }\end{array}$ & $\begin{array}{l}\text { ea has population more } \\
8 \text { millions. }\end{array}$ \\
\hline 24. Man & $\begin{array}{l}\text { Infle } \\
\text { plur }\end{array}$ & $\begin{array}{l}\text { in There are many tourism } \\
\text { parks. }\end{array}$ \\
\hline 25. Ther & $\begin{array}{l}\text { Infle } \\
\text { plur }\end{array}$ & in $\mathrm{Th}$ \\
\hline 26. In Jakarta ma & $\begin{array}{l}\text { Infle } \\
\text { plur }\end{array}$ & $\begin{array}{l}\text { in Jakarta has many tourism } \\
\text { places. }\end{array}$ \\
\hline $\begin{array}{l}\text { 27. Not difficult to find some motel, } \\
\text { hotel, etc. }\end{array}$ & $\begin{array}{l}\text { Infle } \\
\text { plurs }\end{array}$ & $\begin{array}{l}\text { in It is not difficult to find some } \\
\text { motels, hotels, etc. }\end{array}$ \\
\hline $\begin{array}{l}\text { 28. We met other student from other } \\
\text { Pertiwi college. }\end{array}$ & $\begin{array}{l}\text { Inflec } \\
\text { plura }\end{array}$ & $\begin{array}{l}\text { in We met other students } \\
\text { from other Pertiwi collage. }\end{array}$ \\
\hline $\begin{array}{l}\text { 29. Karawang also have a few of } \\
\text { tradition. }\end{array}$ & $\begin{array}{l}\text { Inflectional } \\
\text { plural form }\end{array}$ & $\begin{array}{l}\text { in Karawang also has a few } \\
\text { traditions. }\end{array}$ \\
\hline $\begin{array}{l}\text { 30. There is performance dance } \\
\text { and wayang golek. }\end{array}$ & $\begin{array}{l}\text { Inflectional } \\
\text { plural form }\end{array}$ & $\begin{array}{l}\text { in There are dance and wayang } \\
\text { golek performances. }\end{array}$ \\
\hline 31. There is so many story. & $\begin{array}{l}\text { Inflec } \\
\text { plura }\end{array}$ & so many stories. \\
\hline $\begin{array}{l}\text { 32. Everybody from another city } \\
\text { really want to see it. }\end{array}$ & & $\begin{array}{l}\text { in Ever } \\
\text { really }\end{array}$ \\
\hline
\end{tabular}




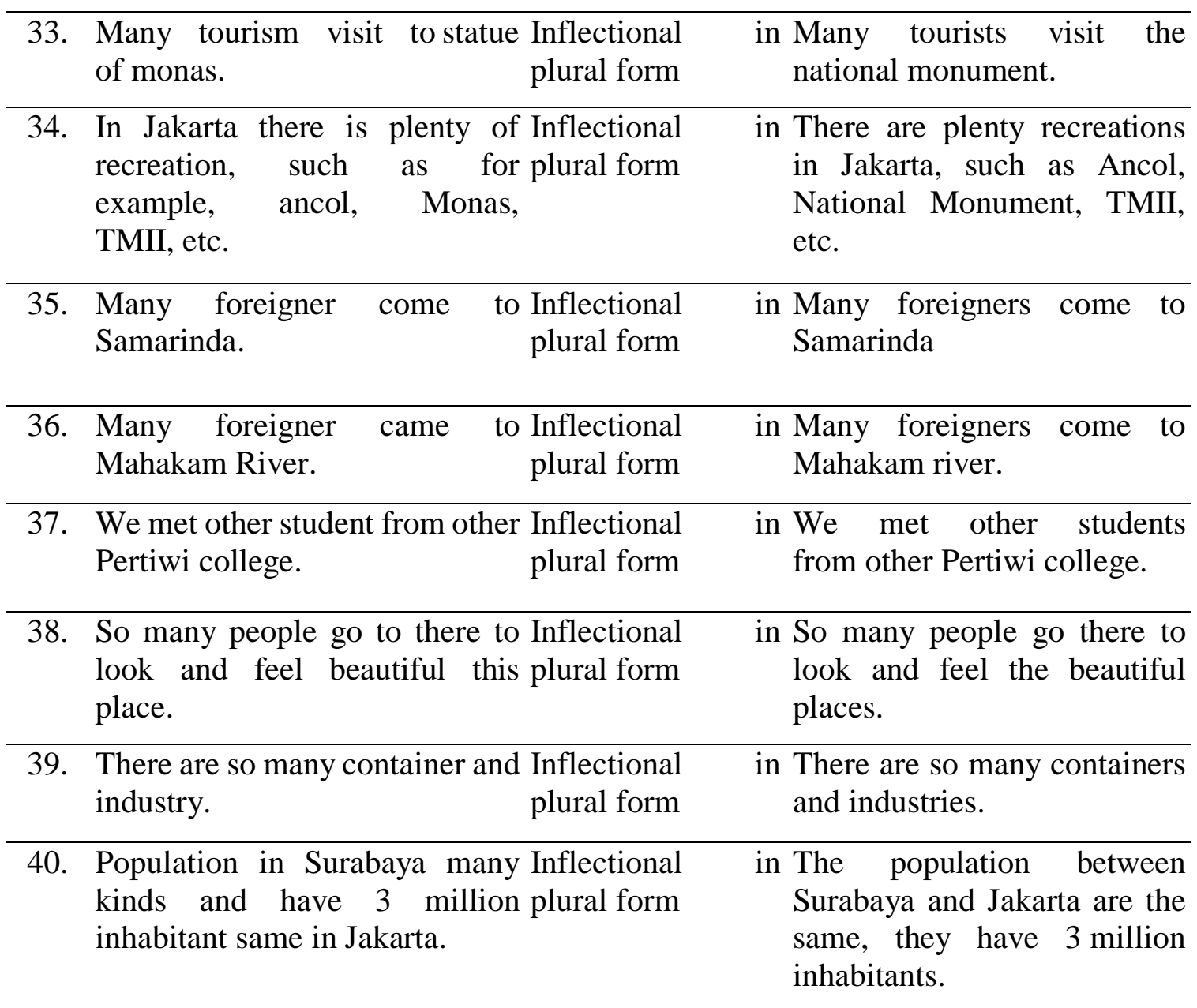

41. Distance from Jakarta to Inflectional Yogyakarta by road thirteen plural form hour. in The distance between Jakarta and Yogyakarta by road is thirteen hours.
42. In Banjarmasin city have more Inflectional three beach with a million miles plural form away. in Banjarmasin has more than 3 beaches.

\begin{tabular}{llcc}
\hline 43. Many building in Surabaya. & $\begin{array}{c}\text { Inflectional } \\
\text { plural form }\end{array}$ & $\begin{array}{c}\text { in There are many buildings in } \\
\text { Surabaya. }\end{array}$ \\
\hline $\begin{array}{l}\text { 44. } \begin{array}{l}\text { Indonesia is rich spices and Inflectional } \\
\text { island. }\end{array} \\
\text { plural form }\end{array}$ & $\begin{array}{c}\text { in Indonesia is rich in spices and } \\
\text { islands. }\end{array}$ \\
\hline
\end{tabular}

Based on the examples above, the students showed that the errors happened in learners' English narrative composition about inflectional in plural form. The researcher analyzes that:

1. The learners don't understand that after the word many, other, some, and plenty of should be plural form. The errors happened because they are lack of knowledge about plural form.

2. The learners don't understand the difference between much and many. Much is uncountable and many is 
countable. The errors happened because they are lack of knowledge about the difference between many and much.

3. The learners don't understand the
45. Yogyakarta is one of Infl beautiful cities in Indonesia. parallelism. The errors happened because of lack of knowledge about parallelism.

4. The learners don't understand the usage of number 2 and up.

46. I want to describe one of Inflectional
seautiful places. $\quad \begin{gathered}\text { in I want to describe } \\ \text { beautiful place. }\end{gathered}$

47. Yogyakarta is one of famous Inflectional places in Indonesia. singular form
in Yogyakarta is one of famous place in Indonesia.

After analyzing on the examples above, the learners showed that the errors happened in learners' English narrative composition about inflectional in singular form. The researcher analyzes that the students don't understand after the word one of them and determiner $a$ should be in singular form. Errors happened because they are lack of knowledge singular form.

\section{So many people lives there. Inflectional in So many people live there. present tense}

49. Many people in Seattle always Inflectional going to the bay in the evening. present tense in Many people of Seattle always go to the bay in the evening.

in You can identify more than 282 fishes.

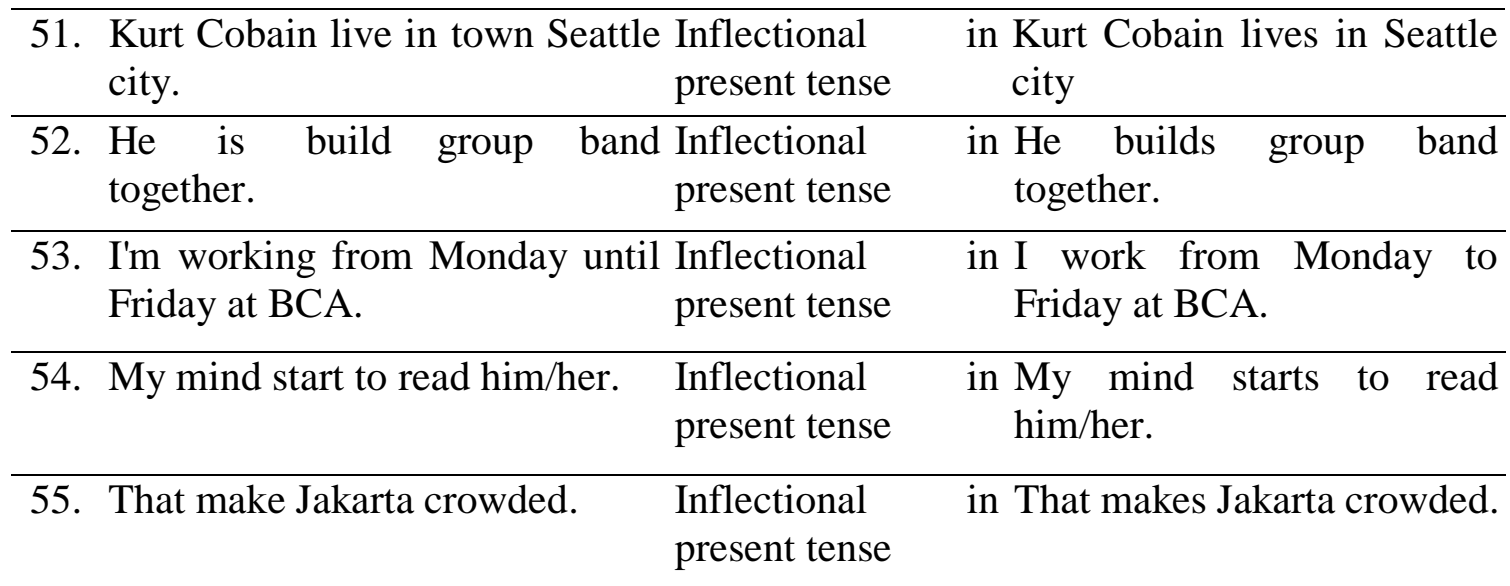

56. The weather of Surabaya Inflectional sometimes make us fells very present tense boring.

in The weather in Surabaya sometimes makes us very boring.

$\begin{array}{llcl}\text { 57. Australian dominated in Bali. } & \begin{array}{l}\text { Inflectional } \\ \text { present tense }\end{array} & \begin{array}{c}\text { in Australian } \\ \text { Bali. }\end{array} & \text { dominates in }\end{array}$




\begin{tabular}{llc}
\hline 58. The transportation just pass a Inflectional & $\begin{array}{c}\text { in The transportation just } \\
\text { present tense } \\
\text { way every day nonstop. }\end{array}$ & $\begin{array}{c}\text { passes a way every day } \\
\text { nonstop. }\end{array}$
\end{tabular}

59. Someone coming to Jakarta for to Inflectional working. present tense in Someone comes to Jakarta for working.
After analyzing on the examples above, the students showed that the errors happened in learners' English narrative composition about inflectional in present tense. The researcher analyzes that:

1. The learners don't understand to differ the verb after plural and singular in present tense. The errors happened because they don't master tenses.

2. The learners don't understand the verb after modal. They think that after modal should be V2 but the correct one is the verb after modal is V1.

3. The students don't understand the usage of simple present.

Another examples are:
We were student went to Cisarua Bogor to got Basic Leader Training Inflectional after to infinitive

We are student of Pertiwi went to Cisarua to get Basic Leader Training

We were student went to Cisarua Bogor to got Basic Leader Training

Inflectional after to infinitive We are student of Pertiwi went to Cisarua to get Basic Leader Training

After analyzing on the examples above, the students showed that the errors happened in learners' English narrative composition about inflectional after to infinitive. The researcher analyzes that the students use V2 after to infinitive. It is absolutely wrong. The correct one is after to infinitive it should be V1.

Derivational Morphology

\begin{tabular}{|c|c|c|c|}
\hline No. & Student's Sentence & \multicolumn{2}{|c|}{$\begin{array}{ll}\text { Types of Error } \quad \text { Reconstruction }\end{array}$} \\
\hline 1. & All residents can fell comfort. & $\begin{array}{l}\text { Derivational } \\
\text { adjective }\end{array}$ & $\begin{array}{l}\text { in All residents can feel } \\
\text { comfortable. }\end{array}$ \\
\hline & I extremely enjoy. & $\begin{array}{l}\text { Derivational } \\
\text { adjective }\end{array}$ & in I am extremely enjoyable. \\
\hline 3. & Pollution is dust and not fresh. & $\begin{array}{l}\text { derivational } \\
\text { adjective }\end{array}$ & $\begin{array}{l}\text { in Pollution is dusty and not } \\
\text { fresh. }\end{array}$ \\
\hline & $\begin{array}{l}\text { Now the Betawi culture has } \\
\text { distinct personality. }\end{array}$ & $\begin{array}{l}\text { a derivational } \\
\text { adjective }\end{array}$ & $\begin{array}{l}\text { in Now the Betawinese culture } \\
\text { has a distinct personality. }\end{array}$ \\
\hline & $\begin{array}{l}\text { In Karawang is still belong int } \\
\text { area west Java majority } \\
\text { Sunda tribe. }\end{array}$ & $\begin{array}{l}\text { Derivational } \\
\text { s adjective }\end{array}$ & $\begin{array}{l}\text { in Karawang belongs to east } \\
\text { Java and Sundanese tribe. }\end{array}$ \\
\hline
\end{tabular}

After analyzing on the examples above, the students showed that the errors happened in learners' English narrative composition about derivational 
in adjective. The researcher analyzes that:

1. The verb after the word feel is always followed by adjective, for example: $I$ feel comfortable.
2. Adjective is also happened after adverb, for example: I am extremely enjoyable.

3. Adjective is also happened before noun, for example: Karawang is Sundanese tribe.

\begin{tabular}{|c|l|lr|l|}
\hline 6. & $\begin{array}{l}\text { Many foreigns come to pulau } \\
\text { Penyu to take picture. }\end{array}$ & $\begin{array}{l}\text { Derivational in } \\
\text { plural forms }\end{array}$ & $\begin{array}{l}\text { Many foreigners come to } \\
\text { Penyu beach to take a picture. }\end{array}$ \\
\hline 7. & $\begin{array}{l}\text { Karawang also have many } \\
\text { cultural in art broad like music, } \\
\text { dance, theater. }\end{array}$ & $\begin{array}{l}\text { Derivational in } \\
\text { plural forms }\end{array}$ & $\begin{array}{l}\text { Karawang also has many } \\
\text { cultures in art broad such as } \\
\text { music, dance, and theater. }\end{array}$ \\
\hline
\end{tabular}

Based on the examples above, the students showed that the errors happened in learners' English narrative composition about derivational in plural form. The researcher analyzes that:

1. The learners don't understand that after the word many should be in plural form. The errors happened because they are lack of knowledge about grammar.

2. The learners don't understand that after the word many should be noun. The errors happened because they are lack of knowledge and carelessness.

\section{CONCLUSION}

Based on some analysis about the errors made by the learners, the followings are the conclusions:

1. The learners don't understand that after the word many, other, some, and plenty of should be plural form.

2. The learners don't understand the difference between the use of many and $m u c h$.

3. The learners don't understand the parallelism.

4. The learners weren't used to write or to make an English narrative composition, the errors happened in morphological level.

5. Recognizing the characters of the learners' error. Most of them haven't mastered yet the target language well so they tended to make mistakes in their mother tongue.

6. Most of the learners' errors happened in the textual errors.

7. Most of them were influenced by their mother tongue, in other hand, they transferred directly to their mother tongue even with grammatically wrong.

8. The errors done by learners perhaps happened because of the teacher don't explain about what he will teach.

9. After having a research on learners' English narrative composition, the errors happened on morphology, syntax, and kinds of error.

\section{REFERENCES}

Akmaijan, A, et. al. (1995). An Introduction to language and Communication. Cambridge Massachusetts: The MIT Press.

Aronoff, M. (2009). Morphology by Itself. Cambridge, MA: MIT Press.

Blair, C., \& Rodman, F. (1990). An Introduction to Language. Sydney: Holt Rinehart and Winston.

Corder, S. P. (1975). Error Analysis and Interlanguage. Hongkong: Oxford University Press. 
Todd, L. (2000). An Introduction to Linguistics. Singapore: Longman York Press.
William, O., et al. (2005). Contemporary Linguistics An introduction $\left(5^{\text {th }}\right.$ Ed). Boston \& New York: Bedford/St Martin's. 